JELTL (Journal of English Language Teaching and Linguistics) e-ISSN: 2502-6062, p-ISSN: 2503-1848

2019, Vol. 4(1)

www.jeltl.org

\title{
A Text-Driven, Task-Based Approach to the Design of Materials for Teaching Intercultural Communicative Competence
}

\author{
John Harper \\ Shantou University, China \\ e-mail:johnh@stu.edu.cn
}

\begin{abstract}
Although a large body of research points to the need of providing English as a Foreign Language (EFL) learners with intercultural communicative competence (ICC), questions remain as to exactly how ICC should be incorporated into the EFL curriculum. These questions arise in part due to issues of already-packed curricula which seem not to leave time for the teaching of ICC and in part due to issues of teacher preparedness. Additionally, questions arise concerning which culture should be taught. Taking into account materials used in the English Language Center (ELC) of Shantou University (Guangdong Province, China), this paper argues that a text-driven, task-based method of materials design allows for the inclusion of ICC across the EFL curriculum. It also argues that such a method lends itself to the teaching of ICC through a consideration of a variety of cultures.

Keywords: intercultural communicative competence, source culture, target culture, task-based learning and teaching, text-driven materials design
\end{abstract}

\section{INTRODUCTION}

In spite of a large body of research regarding the relation between language and culture, the exact place for culture in the English as a Foreign Language (EFL) curriculum seems still not to have been well determined. In some cases, the culture element is seen as "peripheral to the 'real business' of language instruction" (Kearney, 2010, p. 332). This relegation of the culture element to the periphery may result from instructors' feeling that they have a great deal of material to cover in a limited amount of time and therefore assuming that the culture element 


\section{John Harper}

will automatically be covered during language instruction (Byram \& Wagner, 2018; Furstenberg, 2010; Moeller \& Faltin Osborn, 2014). Another explanation for this phenomenon may lie in the fact that language teachers are usually not anthropologists or experts in the field of intercultural communication (Byram \& Kramsch, 2008; Snow, 2015). Hence, the culture element may appear simply to be beyond their professional scope.

Regardless of the supposed complications surrounding the inclusion of the culture element in the EFL classroom, it may be argued that, as English is a global language and as most students will never take a course specifically focused on intercultural communication, the EFL classroom stands out as a prime candidate for the task of teaching intercultural communicative competence (see Snow, 2015, 2016). For the purposes of the present discussion, the term intercultural communicative competence (ICC) will be defined as the "ability to ensure a shared understanding by people of different social identities, and [the] ability to interact with people as complex human beings with multiple identities and their own individuality" (Byram, Gribkova \& Starkey, 2002, p. 10, as cited in Kiet Ho, 2009). The development of such competence is now understood to entail much more than the acquisition of culture-related facts (see Savignon \& Sysoyev, 2005; Snow, 2015; Weninger \& Kiss, 2013). It entails, rather, the placing of the learner "at the intersection of multiple social roles and individual choices" (Kramsch, 1993, p. 234) and the developing in the learner of an openness toward and tolerance for the other (see Cortazzi \& Jin, 1999; Furstenberg, 2010; Moeller \& Faltin Osborn, 2014). There remain, however, questions regarding which culture should be taught and how culture should be taught (Cortazzi \& Jin, 1999; McKay, 2000).

This paper is based on the premise that the culture element, in the form of ICC, should be consciously incorporated into EFL materials even in courses in which ICC is not the primary focus. It will report on a method of materials design that has been used in the English Language Center (ELC) of Shantou University (Guangdong Province, China). Specifically, it will argue the following:

1) A text-driven, task-based materials design method may aid in providing learners with appropriate ICC training even in courses emphasizing other components of language learning.

2) Such a design method lends itself to the teaching of ICC through a consideration of a variety of cultures, not simply through a focus on a target culture or on the source culture.

Prior to an elaboration on the two arguments mentioned above, a brief discussion of the need of consciously incorporating ICC into course materials is in order-as is a discussion of the institutional context and the method used for the two arguments.

\section{LITERATURE REVIEW: THE NEED OF CONSCIOUSLY INCORPORATING ICC INTO COURSE MATERIALS}

As mentioned previously, one explanation given for not taking steps consciously to include the culture element in the EFL curriculum has to do with the notion that, during the process of language instruction, the culture element will somehow present itself automatically. Under such circumstances, the culture element is likely to be "only a setting for the linguistic material" (Cortazzi \& Jin, 1999, p. 201), a setting that is unlikely to add to learners' 
development of ICC. It has also been pointed out above that the simple teaching of culturerelated facts, or what Snow (2015, p. 286) calls "culture learning," is insufficient for the teaching of ICC (see also Perry \& Southwell, 2011). This learning of specific facts will no doubt be beneficial if learners actually visit the culture that they have learned about and actually need to discuss the facts that they have learned. Given current trends toward globalization, however, a student may very well need intercultural communication skills even if he/she never leaves his/her own country. Simply put, a culture component serving to present pure "linguistic material" or to present facts that may never be used fails to lead students toward ICC.

Kumaravadivelu (2002) points out a basic principle underlying the teaching of ICC: "Any cultural construct that is based on interpretations of only one side of the cultural spectrum will remain unprincipled and uninformed for the simple reason that one-sided interpretations can lead only to narrow versions of cultural reality" (p. 4; see also Pulverness \& Tomlinson, 2013). Kumaravadivelu's comment, put into the context of EFL materials, calls for a design method that consciously incorporates two cultures - that of the learner and that of the other. It calls for a type of classroom activity that leads students to create a dialogue between themselves (i.e., their individuality and their culture) and the other, to discover the cultural situatedness of their own ideas and of those of the other, and to appreciate cultural similarities and differences through an understanding of the impact of culture on beliefs, opinions, and values (see Kiet Ho, 2009; Scarino, 2010; Sercu, 2002). In short, the comment calls for materials that help to stimulate the sort of classroom activity that leads to a "reflexive, open, and globally aware language learner" (Weninger \& Kiss, 2013, p. 695).

While the EFL classroom environment, distant as it often is from other cultures, may not initially appear to be the ideal place for the creation of the aforementioned dialogue (see Kearney, 2010; Perry \& Southwell, 2011), it comes across more positively if one considers the learner's role not as that of a passive recipient of information but as that of an intercultural participant who "creates meaning" (Kramsch, 1993, p. 236, italics as in original). Viewed from such a perspective, the classroom becomes a place where the learner can agree or disagree with the other, where he/she can agree or disagree with his/her own cultural norms - in short, where he/she can become a knowledgeable individual making informed personal choices (see Cortazzi \& Jin, 1999; Kramsch, 1993; Menard-Warwick, 2009). Ultimately, then, a classroom environment fostering ICC must be one in which cultural meaning is "socially constructed" by the "key participants in the learning process: students, teachers, and materials" (Weninger \& Kiss, 2013, p. 695).

\section{INSTITUTIONAL CONTEXT}

Shantou University (STU), a key provincial university in Guangdong Province (China), maintains a student enrollment of roughly 10,000, with approximately 8000 of those students being in the more emphasized undergraduate program, the program serving as the source of data for this paper. Full-time students of the undergraduate program are almost entirely from Mainland China. As Shantou is far from being one of China's more cosmopolitan cities, it is safe to say that students' daily contact with non-Chinese people comes largely from their contact with international teachers and with short-term exchange students. However, by providing reimbursements on IELTS fees for students who achieve a score of 7.0 or more, and by engaging in agreements with many international institutions (e.g., Whitman College, University 


\section{John Harper}

of Calgary), STU strives to provide its students with study-abroad opportunities. In 2017, the latest year for which there are statistics, 1,381 students were chosen to participate in international exchange programs. This figure, it should be noted, includes short-term stays in Hong Kong, Macau, and Taiwan but does not include students who studied abroad on their own accord (i.e., without STU support).

With the exception of students from the Medical College, the ELC offers classes to all undergraduate students. Most students, regardless of their majors, go through a four-semester, 16-credit suite of courses appropriately labeled ELC-1, ELC-2, ELC-3, and ELC-4. A remedial course, ELC-Foundations, is also offered. For students of Art and Design and for students of Global Law, the normal suite of courses is replaced with discipline-specific courses (i.e., English through Art and Global Law English, respectively). The ELC Program is highly supplemented with a variety of elective courses (e.g., Voice \& Accent Training, Art \& Culture) and with a variety of co-curricular activities (e.g., English through Drama \& Conversation, Current Events). The curriculum as a whole is based on Five Golden Rules of English Learning: proficiency, autonomy, sustainability, intercultural competence, critical thinking.

\section{RESEARCH METHOD}

This paper is based on the method of participant observation. As the goal was to determine how course materials of the ELC serve to aid students in the development of ICC, a careful scrutiny of course syllabi and of course materials was carried out; ongoing class observations were conducted; the author's own experience as a teacher of the ELC was of course taken into account. In keeping with other findings (see Bao, 2013; Jolly \& Bolitho, 2011; Pulverness \& Tomlinson, 2013), the analysis concluded that tailor-made materials, some produced within the ELC and some commercially produced for a Chinese audience, best allowed students to be themselves and at the same time simulate "the sorts of communicative activities which are required of them outside" (Nunan, 1988, p. 97; see also Bao, 2013; Henry, Korp, Sundqvist, \& Thorsen, 2017). The analysis also concluded that, while various techniques were employed in the ELC to develop learners' ICC, text-driven, task-based techniques appeared to be the most common.

For the purposes of analysis, three sample tasks were chosen, each from a different ELC course. The courses and a very brief description of them (taken from course syllabi) are provided below:

- ELC-3 (intercultural communication): "This is a content-based integrated skills course focusing on intercultural communication and discussion skills."

- ELC-1 (integrated skills): "This is an integrated skills course that focuses on all four major language skills and also on building students' ability to learn languages effectively."

- GLE-1 (global law): "This integrated skills course focuses on all four skills - reading, writing, speaking and listening. As the course is specifically for Law Majors, some lessons will deal specifically with law-related issues."

The decision to choose tasks from a variety of courses reflects a belief that no one course can prepare students for the plethora of factors involved in ICC (see Snow, 2015). It also reflects 
a belief that any text will necessarily be full of culturally laden information (see Baker, 2012; Pulverness \& Tomlinson, 2013) and that culture (hence, ICC) may be consciously taught with any well-chosen text, not only with a text selected for a course specifically oriented toward ICC. The goal, ultimately, is for the culture element to be presented through texts which lead to tasks and through tasks which lead to a reflection on the beliefs and values presented in the text and on the beliefs and values on which the learners' own opinions are based (see Saraceni, 2013; Tomlinson, 2013a; Webb, 2009; Weninger \& Kiss, 2013).

\section{DESCRIPTION OF CHOSEN TASKS}

\subsection{ELC-3: Debate within the Debate Team: A Critical Incident Exercise (CIE)}

As Snow (2014) points out, "Critical incident exercises start with the presentation of a story describing a problematic encounter between people from two different cultures, an encounter in which there is some kind of cultural misunderstanding" (p. xiv; see also Snow, 2015). The particular CIE chosen for analysis here is intended to lead students to reflect on issues of (a) ingroups and outgroups and (b) possible cultural differences related to the following of rules. It is implemented as a follow-up activity to readings on and discussions of these two topics (see readings and discussions in Snow, 2014). The institutionally created CIE is quite short and thus can be reprinted in full here:

DEBATE WITHIN THE DEBATE TEAM: INGROUPS/OUTGROUPS--EXCEPTIONS TO THE RULE: Huan-Yue, originally from a small province in China, is currently a senior at a university in Great Britain. As she has won several awards for her debating skills, she has been asked to serve as an advisor for this year's university debate team. The team is now in the fourth week of a 16-week training period. Curiously enough, just last week a very talented debater named Hugo approached Huan-Yue and expressed interest in joining the debate team. Hugo apologized for not joining earlier and mentioned some serious family issues that had demanded his attention. Huan-Yue, understanding Hugo's situation and also realizing the poor state of the debate team, promised Hugo a place on the team. But when Huan-Yue mentioned Hugo to others (i.e., to her fellow advisors and to debate-team members), she was greeted with lots of criticism. Her critics all insist that the team was formed four weeks ago and that no exceptions can be made.

- In what ways can this situation be interpreted?

- What, if anything, can be done to improve this situation?

As the questions following the story indicate, the CIE is of the open-ended type (see Snow, 2014, 2015). Students, working in small groups, are expected to come up with various logical interpretations of the problem; they are not expected to form the one and only correct answer. The task concludes with a whole-class discussion of different interpretations of the situation.

\subsection{ELC-1: Finding Mr./Ms. Right.}

The Finding Mr./Ms. Right task employed in ELC-1 leads students to reflect on cultural issues regarding dating and marriage choices. Coming after the reading of a text in which a British man discusses his experience with love at first sight, the task operates on the principle 


\section{John Harper}

that "[1] earners think, say and learn more if they are given an experience or text to respond to than if they are just asked for their views, opinions and interests" (Tomlinson, 2013b, p. 25; see also Tomlinson, 2010). Once the text is analyzed, the students, divided into small groups, are given a stack of cards placed face down, with each card providing one comment from a writer of a personal ad. That is, there are many cards placed face down, but all comments come from the same personal ad writer. A selected sample of the cards is given below:
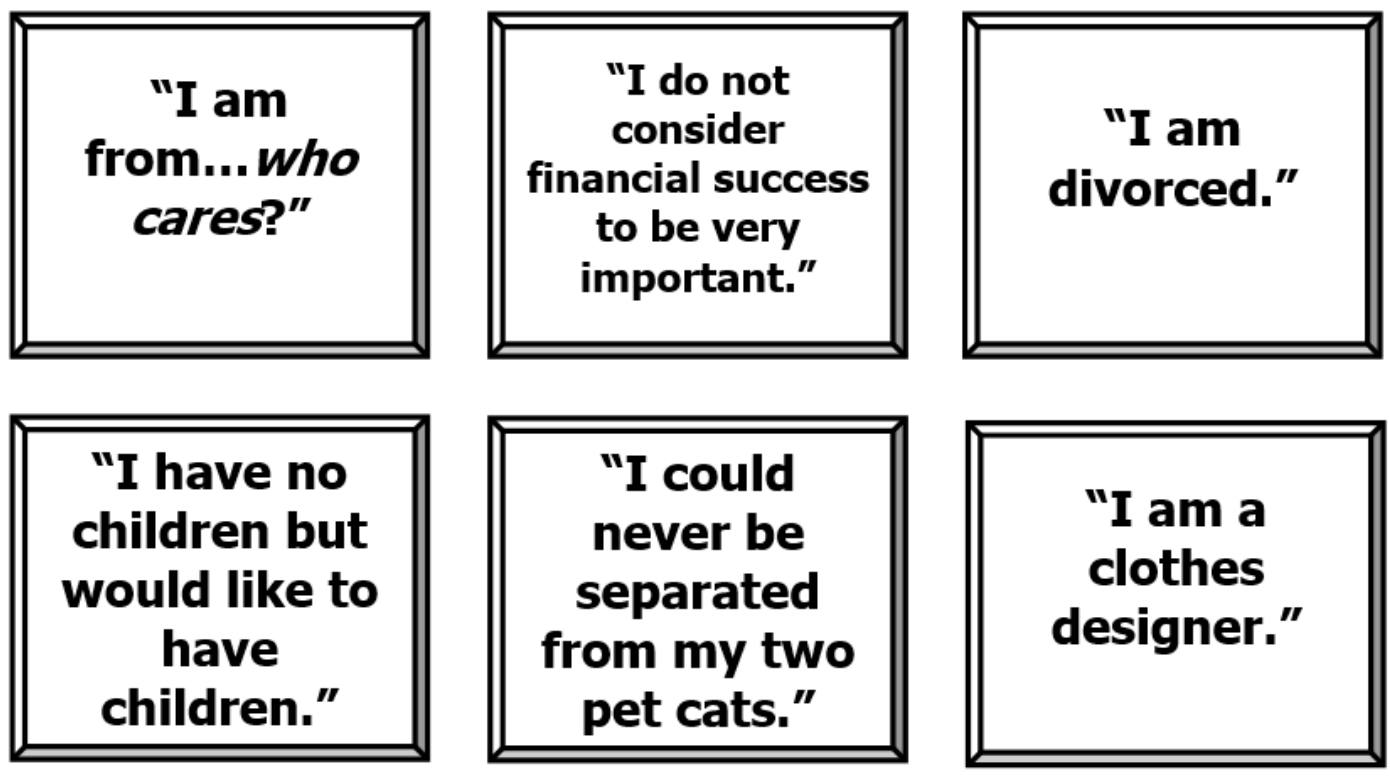

Figure 1: Sample Cards from Finding Mr./Ms. Right

Though the writer is in fact a Brazilian male, neither the gender nor the nationality of the writer is initially revealed, and all comments are gender neutral. The students are simply told that the writer is not Chinese. The students, working in small groups, turn over the cards one by one and, with each new card, discuss with fellow group members whether or not they feel that the writer of the ad would make a suitable partner for a relationship. Finally, once the content of each card has been discussed and analyzed within the group, group members make individual decisions as to whether or not the ad writer would make a suitable partner. The task concludes with a whole-class wrap-up discussion in which opinions and the rationale behind the opinions are shared and debated.

Like the CIE described above, the task is open in that it does not require students to arrive at one right answer, and students know that different outcomes are possible (see Ellis, 2003; Nunan, 2004; Prabhu, 1987; Skehan, 1998). Furthermore, as the task requires group discussion about individual views, it encourages a healthy dose of disagreement intended to promote more active engagement (see Webb, 2009). 


\subsection{GLE-1: Dog on the Loose: A Case for the Livability Court.}

The Dog-on-the-Loose task, like the other tasks described here, comes after the reading of a relevant text. In this case, the text deals with the livability court, a court focusing specifically on minor disruptions of the civility of a US town and headed by a judge known to dish out harsh punishments to citizens who commit such infractions as letting pet dogs get out of control or failing to keep front yards in order. A small-group discussion of the feasibility of the livability court in China follows the reading. Then, students are divided into groups of six, with each group of six being divided into three pairs. One pair serves as NEIGHBOR A, another as $N E I G H B O R B$, and another as JUDGE. Each pair is given its respective role in accordance with the roles shown below:

\section{NEIGHBOR A: \\ "My neighbor's dog leaves droppings all over the place!!!"}

Your neighbor does nothing to keep his/her dog under control. The dog runs loose in the street. And the dog frequently leaves dog droppings on the sidewalk, on your doorstep, and next to your car. You have talked to your neighbor about this problem before, but he/she just tells you that "The dog is man's best friend." You want your neighbor's dog to have to stay inside your neighbor's house.

Take your case to the livability court. Try to get a solution in your favor.

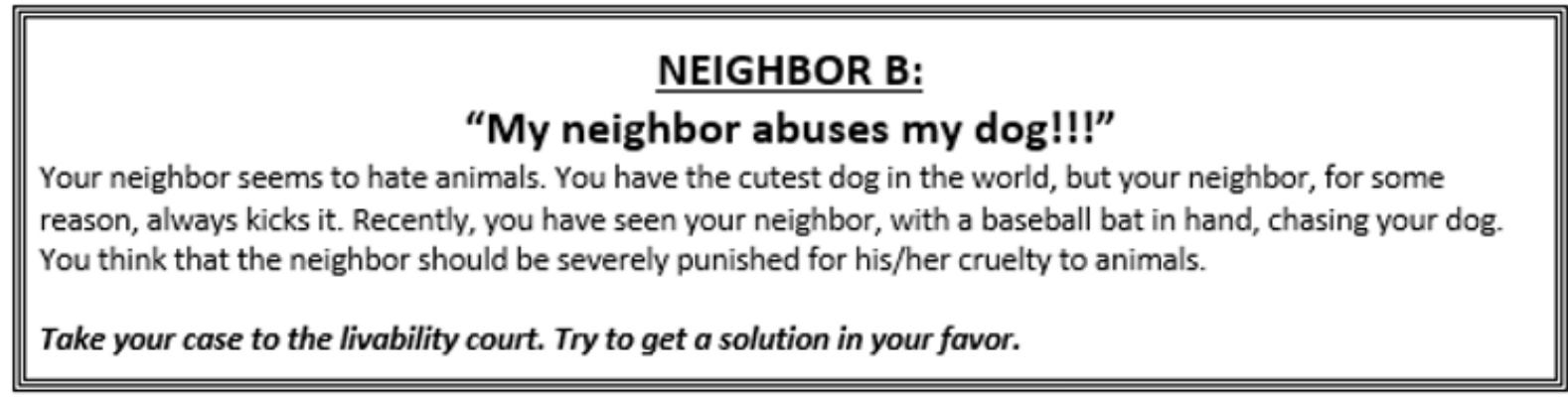

\section{JUDGE}

A case will be brought to you today by two feuding neighbors. One neighbor (NEIGHBOR A) accuses the other neighbor (NEIGHBOR B) of not controlling his/her dog. NEIGHBOR B, incidentally, accuses NEIGHBOR A of abusing his/her dog.

Ask questions; find out the facts of the case; and come to a decision in the case.

Figure 2: Role Cards from Dog-on-the-Loose

After five minutes of preparation, the various pairs of judges hear the cases brought forth by the various pairs of neighbors. The task requires some creativity from all pairs within any 


\section{John Harper}

particular group. Hence, different groups inevitably take the task in different directions - as is expected if task-based learning and teaching (TBLT) is viewed from a sociocultural perspective (Skehan, 2003; see also Skehan, 1998; Van de Branden, 2009). The task is divergent in that it requires disagreement among participants (see Ellis, 2003; Skehan, 1998). Specifically, each pair of neighbors has to defend its assigned position and refute the arguments of the other pair of neighbors. The outcome of the task is reached when the various pairs of judges announce their respective verdicts.

\section{TEXT-DRIVEN AND TASK-BASED MATERIALS DESIGN AND ICC 6.1 Text-Driven Materials Design and ICC}

The text-driven approach to materials design effectively reverses a long-standing method based on teaching points. Allwright (2005), a strong critic of teaching toward teaching points, defines them as "bits of the target language" that a teacher should cover in a lesson and that students should learn in a lesson (p. 9). Such a pedagogical approach suggests that teachers/materials designers are able to dictate learning. The classroom experience, however, indicates that students and teachers may often have very "different agendas" (Nunan, 1995, p. 140; see also Allwright, 1984). As Nunan (1995) puts it, "While the teacher is busily teaching one thing, the learner is very often focusing on something else" (p. 135). Crabbe $(2003,2007)$ shifts the focus of instruction from teaching points to learning opportunities. He defines the term learning opportunity as "a specific cognitive or metacognitive activity that a learner can engage in that is likely to lead to learning" (2007, p. 118).

In keeping with a focus on learning opportunities, Tomlinson (2013a) presents the textdriven approach to materials design, an approach which requires, first, the selection of relevant and stimulating texts and, second, the specification of teaching points around the chosen texts. In other words, the approach calls for texts to determine teaching points, not for teaching points to determine texts. With a "library of potentially engaging texts" on hand (Tomlinson, 2013a, p. 100), the teacher/materials designer can choose texts which (a) fit learners' needs and interests and (b) aid in the teaching of content appropriate for learners. This focus on relevant and stimulating texts suggests that the text itself, by engaging learners in a topic of interest, may lead learners to take advantage of the learning opportunities provided through teaching points and/or to create their own learning opportunities.

As indicated above, the starting point for developing text-driven materials consists of the finding or developing of texts that will lead to student engagement, with engagement being defined as "a willing investment of energy and attention in experiencing the text in such a way as to achieve interaction between the text and the senses, feelings, views and intuitions of the reader/listener" (Tomlinson, 2013a, p. 100). To determine whether or not a found or created text is relevant for use in the classroom, Tomlinson (2013a) asks several questions, among which are the following:

- Are the target learners likely to be able to connect the text to their lives?

- Are the target learners likely to be able to connect the text to their knowledge of the world?

- Is the text likely to stimulate divergent personal responses from the target learners?

- Is the text likely to contribute to the personal development of the learners? (p. 101) 
If the answer to these questions (and others) is YES, the text is suitable. The materials designer's job, however, is far from over. The materials designer needs, for example, readiness activities - that is, activities which attempt to lead learners to make important connections between their own lives and their own experiences on the one hand and the forthcoming text on the other (Tomlinson, 2013a; see also Bao, 2013). Also needed are intake response activitiesthat is, activities which allow learners "to share with others what the text means to them" (Tomlinson, 2013a, p. 104). And the design process necessarily entails development activities intended to provide learners with the opportunity to use language in original ways in order to build on the meanings they have obtained from the text (Tomlinson, 2013a).

The consistency between such a materials design perspective and the teaching of ICC is apparent. In both, learners are led to create a dialogue with a text, not simply to absorb knowledge transmitted through it (see Cortazzi \& Jin, 1999). Learners create this dialogue in English but "from their experiential situatedness in their own language and culture" (Scarino, 2010, p. 326; see also Kramsch, 1993; Tang, 2006). In the end, they create original meaning in English not from the point of view of the other but from the point of view created through their interaction with the culture elements presented in the text. A further consideration of the CIE Debate within the Debate Team presented above should aid in clarifying this point.

As previously mentioned, the given CIE takes place after students have read and discussed matters of ingroups/outgroups and of the following of rules. At the time of carrying out the CIE in small groups, students will already have learned that Chinese culture, unlike many Western cultures, is typically considered to be collectivist (though of course no broad generalization can or should be made). They will also already have learned that ingroup membership tends to take on greater importance in collectivist cultures and that the breaking of rules for ingroup members is more tolerated in some cultures than in others (see Gudykunst, Lee, Nishida, \& Ogawa, 2005; Snow, 2014). In short, they will have been given some general information and will have been asked to reflect on it. Upon considering the CIE itself, they will probably notice some particularities about it:

- Huan-Yue is from a traditionally collectivist culture and might therefore be inclined to help an ingroup member.

- Hugo, however, does not appear to have had any prior ingroup status with Huan-Yue.

- Hugo has had "family issues" (i.e., issues with ingroup members) and thus might be considered to have a reasonable excuse for joining the debate team rather late in the game.

- The other people involved (i.e., "fellow advisors" and "debate-team members") take a clearly ingroup stance and do not seem accepting of the idea of breaking rules for an unknown outsider.

- As the incident takes place at a British university, it would seem logical to assume that some of the "fellow advisors" and "debate-team members" are probably British. However, since nationalities are not given, one cannot be sure of the cultural background of the others.

The CIE, then, taken as an open-ended means of teaching ICC, does not demand one specific response from learners. Rather, it encourages them to pay attention to the "key factors" of a situation and to consider "multiple interpretations of puzzling or problematic things 


\section{John Harper}

strangers do and say" (Snow, 2015, p. 287; see also Snow, 2016; Spencer-Oatey \& Franklin, 2009). Taken as an example of a development activity of text-driven materials design, the CIE leads learners toward a variety of responses and allows them the freedom to personalize the activity and thus to take it in the direction of their preference (Tomlinson, 2013a; see also Saraceni, 2013). In other words, whether regarded as a means of teaching ICC or as a result of text-driven materials design, the CIE provides learners with "a way of making a cultural statement" (Kramsch, 1993, p. 237).

\subsection{Task-Based Materials Design and ICC}

Ellis (2009) rather succinctly sums up the basic requirements of a task:

1. The primary focus should be on "meaning" (by which is meant that learners should be mainly concerned with processing the semantic and pragmatic meaning of utterances).

2. There should be some kind of "gap" (i.e., a need to convey information, to express an opinion or to infer meaning).

3. Learners should largely have to rely on their own resources (linguistic and nonlinguistic) in order to complete the activity.

4. There is a clearly defined outcome other than the use of language (i.e., the language serves as the means

for achieving the outcome, not as an end in its own right) (p. 223; see also Ellis, 2011).

Although there are many differences of opinion concerning exactly what constitutes a task (see Ellis, 2003; Nunan, 2004; Skehan, 1998), the four principles stated above appear repeatedly in TBLT-related literature. Nunan (2004), for example, states that a task must involve a need to "express meaning" and must produce a "sense of completeness" [i.e., an outcome] (p. 4). Willis (1996), as another case in point, notes that tasks do not allow learners to depend on prerehearsed language, thus suggesting that learners must "rely on their own resources" in order to complete a task. And Prabhu (1987) stressed the need of a focus on meaning and of a gap in task design. The central tenets of a task, then, seem to be somewhat agreed upon. Relevant to the present paper are a few of the many divisions into which tasks may be divided.

Reference has been made above to open tasks and to divergent tasks, with the former being those which do not require a particular right answer (i.e., a particular outcome) and the latter being those which specifically require learners to argue for different outcomes. Although divergent tasks are, not surprisingly, contrasted with convergent tasks (i.e., those which require learners to agree on an unspecified outcome), "[ $\mathrm{t}]$ he divergent/convergent distinction is best seen as a subcategory of open tasks" (Ellis, 2003, p. 90; see also Ellis, 2010). In both cases, the outcome is subjective, based on students' opinions. In closed tasks (e.g., a spot-the-difference activity), on the other hand, only one answer is correct (see Ellis, 2003; Skehan, 1998). Evidence suggests that closed tasks lead to more negotiation of meaning, a key principle of TBLT (see Ellis, 2003), and arguments can be made for providing students with the security of clear "right or wrong outcomes" (Prabhu, 1987, p. 47). However, for the purposes of teaching 
ICC, open tasks would seem to go further in encouraging students to consider aspects of the other with an open mind, to reflect on their own culture with an open mind, and to reflect on their own unique beliefs and values with an open mind (see Snow, 2015).

Cortazzi and Jin (1999), citing Luke (1989), distinguish between open and closed texts. While closed texts show an "unproblematic world that confirms or reinforces learners' views and beliefs," open texts encourage "a range of possible interpretations, elaborations, and learner responses" (p. 208). An open text, then, is "deliberately incomplete" in order to provoke "cognitive or emotional involvement" (Cortazzi \& Jin, 1999, p. 208; see also Mercer \& Howe, 2012; Saraceni, 2013). The Finding Mr./Ms. Right task described above, a task based on a previously read text concerning the inevitably engaging (and open) topic of love, serves as an example of such deliberate incompleteness.

As the selected cards of the Finding Mr./Ms. Right task reveal, the task leads to a great deal of other-questioning, own-culture questioning, and self-questioning. For example:

- For some people, nationality is not an important factor in a relationship. Why not? Is it important in China? Is it important for me?

- For some people, money is not an important factor in a relationship. Why not? Is it important in China? Is it important for me?

- For some people, there seems to be no real stigma linked to divorce. Why not? Is there a stigma linked to divorce in China? Do I feel that there is a stigma linked to divorce?

Skehan (2002) notes that tasks can be a "vehicle for individualization" (p. 291). In his discussion, he refers specifically to the individualization of language development and does not focus on ICC. However, if attention is drawn to the culture element that is always present in the classroom (see Kramsch, 1993; Weninger \& Kiss, 2013), it is clear that TBLT techniques may lead students to reflect on their own identity, on their own place within their own culture, and on their own place in relation to other contexts in which they may find themselves in the future (Byram \& Wagner, 2018; Durocher, 2007). In short, task-based materials design, when directed toward ICC through open tasks based on open texts, may aid in the development of the sort of "critical cultural awareness" required of learners regardless of whether their intercultural encounters take place within their own cultures or within other cultures (Byram, 1997, p. 53).

\subsection{Linking Text-Driven and Task-Based Materials Design to ICC}

This paper has so far discussed text-driven and task-based approaches to materials design more or less separately; hence, the exact manner in which the two approaches might be combined in the teaching of ICC has been more insinuated than directly expressed. The present sub-section seeks to show more precisely the way in which the two approaches, when combined, may lead to an effective and well-scaffolded approach to the teaching of ICC, with the term scaffolding being defined here as "the dialogic process by which one speaker assists another in performing a function that he or she cannot perform alone" (Ellis, 2003, pp. 180-181). Specifically, it argues that a text-driven approach may provide useful pre-task scaffolding and that a task-based approach may provide opportunities for the type of peer scaffolding necessary for learners in an EFL environment to acquire ICC even though they may be far from any culture but their own. 


\section{John Harper}

Task-based language teaching, as opposed to task-supported language teaching, places the task itself as the central element of instruction (Ellis, 2010; see also Kim, Jung, \& TracyVentura, 2017; Nation \& Macalister, 2010; Nunan, 1988; Richards, 2001; Robinson, 2011; Skehan, 2002). Nevertheless, advocates of TBLT have repeatedly stressed the need of the pretask (see Ellis, 2003; Prabhu, 1987; Skehan, 1998). As proposed by Prabhu (1987), the pre-task was essentially a public display of a task similar to the actual task that students would need to perform. Ellis (2003) and Skehan (1998), while acknowledging this possible function of a pretask, have shown that the pre-task may serve many other purposes, two of which are "engaging learners in non-task activities designed to prepare them for the task" (Ellis, 2003, p. 245; see also Bao, 2013; Dörnyei, 2001) and "introducing new elements into the interlanguage system" (Skehan, 1998, p. 137; see also Nunan, 2004). It is by serving these two purposes that a textdriven approach to materials design may complement TBLT and aid in the teaching of ICC.

As mentioned above, the Debate-within-the-Debate-Team task related to ingroups and outgroups and to the following of rules is implemented after readings dealing with the relevant topics. The readings familiarize students with such terms as ingroup, outgroup, individualism, collectivism and at the same time set the tone for the upcoming CIE. Hence, the readings (and the subsequent discussions based on them) provide vocabulary useful for successful completion of the task and also prepare students emotionally for it. The third task described above (i.e., Dog on the Loose) is preceded by a text describing the rather unusual legal phenomenon of a judge getting involved in what seem to be fairly petty neighborhood disturbances. Hence, by presenting students with the "novelty element" (Dörnyei, 2001, p. 76, italics as in original), it "whets the students' anticipation of the task" (Dörnyei, 2001, p. 78). At the same time, relevant vocabulary (e.g., nuisance, misdemeanor) is introduced into the students' repertoire. Intake response activities then allow learners to share their opinions concerning the necessity (or lack thereof) of having a livability court in China.

One might say that the scaffolding provided by the texts in the previously discussed activities takes a rather "top-down format" (Harper \& Chen, 2018, p. 25), with the teacher and/or materials designer serving as the expert who provides presumably less capable individuals (i.e., the students) with the tools that they will need to complete the forthcoming task (see Block, 2003). It is known, however, that effective scaffolding is not limited to the expert/less-capable- individual dichotomy. Naughton (2006) points out that, during the classroom learning process, learners may become "mutual scaffolders" who aid each other in the completion of a task (p. 170); Lantolf and Thorne (2006), citing Donato (2004), note that learners working together may form a sort of "collective expert" (p. 283; see also Oxford, 1997; Wells, 1999). In discussing TLBT in particular, Skehan (2002) observes that "tasks can enable two learners to collaborate and go beyond their individual competences" (p. 291; see also Ellis, 2003; Skehan, 2003).

The transition from text-driven, pre-task activities to the task itself marks a transition from "top-down" scaffolding to peer scaffolding. In preparing for the mock court case advocated in the Dog-on-the-Loose task, pairs will need to question their own beliefs and compare their beliefs to those of their partners. In moments of uncertainty, one member of a pair may help his/her partner to clarify or better formulate beliefs. Granted, the debate-type format of the task will lead the neighbor pairs to want to "win" at all costs. Hence, it is possible that a member of a 
neighbor pair may temporarily suspend his/her real beliefs in an effort to "win." The judge pairs, ultimately, will be the ones who choose the winners. Behind their decisions will lie their beliefs concerning the necessity (or lack thereof) of judiciary interference in neighbor disputes as well as their beliefs concerning the rights that should be granted to animals. The members of any judge pair will need to work together so that each member may formulate and articulate his/her beliefs on these issues. A comparison of beliefs and opinions will necessarily take place. Posttask discussion, based largely on the judges' announcements of their verdicts, will lead to more of the type of comparing and questioning that should allow learners to "become more prepared for exploring another culture and interacting with people from that culture" (Moeller \& Faltin Osborn, 2014, p. 681).

\section{DETERMINING WHICH CULTURE TO TEACH}

As mentioned previously, this paper is based on the premise that ICC should be consciously included in EFL materials even in cases in which a course has a different primary focus. Hence, the Dog-on-the-Loose task, while having as a primary focus the teaching of English related to the discipline of law, includes a culture component. Such a premise stems from the belief, also mentioned previously, that all texts (and therefore all activities based on texts) are inherently laden with cultural information (see Baker, 2012; Pulverness \& Tomlinson, 2013). There remains, however, the issue of which culture should be taught (see Cortazzi \& Jin, 1999; McKay, 2000). The forthcoming discussion will briefly analyze (a) arguments for teaching toward a target culture and (b) arguments for teaching toward a source culture. It will then present a rationale for using tasks to teach toward a variety of cultures - especially when the culture element is considered to be a conscious but underlying component of materials design.

\subsection{Teaching toward a Target Culture}

Pulverness and Tomlinson (2013) make the following statement: "Even when neither partner in a spoken or written interaction is a native speaker, the language they are using is the result of social and historical circumstances which give it resonance and meaning" (p. 446). Walker (2000) states that learners of a second language must make use of the "inculcated default memories" of the culture associated with that language (p. 233). Tang (2006) points out that successful communication is possible because individuals with similar "ethnic experiences" and "life experiences" are able to co-construct meaning (p. 88). Such arguments stem from the notion that "language and culture are inextricably intertwined" (Pulverness \& Tomlinson, 2013, p. 446; see also Kramsch, 1993; Savignon \& Sysoyev, 2005), a notion that is difficult to refute and that will not be refuted here. In an EFL context, however, the goal of teaching toward a target culture becomes somewhat problematic.

Within a university EFL context, learners approach the language with a variety of motivations. Some may view the language as a vehicle for obtaining employment. Others may view it as a vehicle for study abroad opportunities. Still others may view it as merely a requirement within a larger program of study. While needs analysis will aid significantly in defining learners' goals and needs (see Nation \& Macalister, 2010; Nunan, 1988), it is unlikely to define a particular target culture on which the instructor and/or materials designer may focus. Different learners will have different target cultures in mind. Furthermore, some materials aimed 


\section{John Harper}

at a supposed target culture may prove to be completely inaccessible to EFL learners. McKay (2000) provides an explanation of how inaccessible a discussion of American garage sales would be for Iranian students (see Bao, 2013; Jolly \& Bolitho, 2011; Sercu, 2002 for more examples of culturally inaccessible materials). Finally, as Cortazzi and Jin (1999) note, learners may not be especially interested in the culture identified with the language they are learning (see also McKay, 2000). Given the possibility of learners' not being able and/or not wanting to identify with a particular other culture, and given the reality that English is not owned by any one country (see Widdowson, 1994), the EFL instructor and/or materials designer would seem to serve learners more effectively when he/she employs the philosophy of "respect for learners as they use English for self-expression" (Savignon, 2003, p. 58).

\subsection{Teaching toward a Source Culture}

Materials design methods focusing on the source culture (i.e., the learners' own culture) would seem to be based largely on two principles: (a) that of enabling learners to share their own culture with others (see Cortazzi \& Jin, 1999; McKay, 2000; Smith, 1976) and (b) that of enabling learners to develop their own cultural identity (see Cortazzi \& Jin, 1999). As stated above, an international language such as English can hardly be said to be owned by any one country (see Widdowson, 1994). Hence, it is reasonable to suppose that an EFL learner may use English to talk about his/her own culture, a supposed target culture, or any other culture. Few would argue against empowering EFL learners to talk about their own culture. Likewise, a learner's cultural identity, though altered during the process of learning an additional language (see Kramsch, 1993), should be respected at all costs.

Ironically, a pure focus on the source culture would seem to deprive EFL learners of exactly the opportunities that it claims to give them. Snow (2015) argues that the "ultimate goal" of English courses should be "to prepare students for direct or indirect interaction with the peoples and cultures of the world" (p. 286). As mentioned previously, the development of ICC places learners "at the intersection of multiple social roles and individual choices" (Kramsch, 1993, p. 234). By focusing only on culture elements with which learners are at least tacitly familiar, the instructor and/or materials designer effectively withholds from the learner the tools that he/she will need to explain his/her culture to the other and keeps him/her in an enclosed world lacking exposure to the various "social roles and individual choices" needed for identity formation and required in successful intercultural communication. In short, materials that fail to provoke a degree of cultural comparison and contrast and a degree of reflection stimulated by such comparison and contrast are unlikely to aid in the development of interculturally communicatively competent learners (see Cortazzi \& Jin, 1999; Kramsch, 1993).

\subsection{Teaching toward a Variety of Additional Cultures}

If teaching toward a particular target culture is unlikely to satisfy all EFL learners and likely to prove inaccessible for some, and if teaching toward the source culture denies learners exactly what it claims to provide, one may logically conclude that the teaching of ICC should revolve around materials that present a variety of cultural points of view and lead students to compare and contrast their own cultural situatedness with a variety of other, equally valid cultural positions. As Snow (2015) points out, the teaching of ICC is about helping learners to 
"build a limited range of skills and habits" that will serve their needs in any intercultural encounter (p. 286; see also Baker, 2012; Snow, 2016; Spencer-Oatey \& Franklin, 2009). In other words, such "skills and habits" should aid learners regardless of whether they use English to communicate with a member of the inner-circle countries, a member of the outer-circle countries, or a member of the expanding-circle countries (see McKay, 2000). Sometimes, the "cultural representations" provided in materials may be "conflictual," yet such representations, if relevant and accessible, allow learners the opportunity "to identify their own cultural resources" and to compare those resources to those of others (Menard-Warwick, 2009, p. 32). In short, the other culture presented may vary; the degree to which in-class activity promotes dialogue with the other culture will determine the success of materials in promoting ICC (see Cortazzi \& Jin, 1999; Weninger \& Kiss, 2013).

The tasks described in this paper all rest on the rather simple principle of group dynamics - that is, on the principle that students working in groups are able to produce more than an individual student would produce relying solely on his/her individual resources (see Dörnyei \& Malderez, 1997; Dörnyei \& Murphey 2003; Oxford, 1997). They are based on the idea that a task takes a particular shape according to the way in which the learners themselves shape it (Seedhouse, 2005; Skehan, 2003; Van den Branden, 2009). Hence, a task allows the students themselves to form their own basis of self-expression (see Savignon, 2003). In terms of the acquisition of ICC, the tasks allow learners to form a classroom culture aimed at critically analyzing their own culture while simultaneously analyzing the other culture (regardless of what the other culture may be) (see Moeller \& Faltin Osborn, 2014; Perry \& Southwell, 2011). Hence, while analyzing the CIE Debate within the Debate Team, students will take into account the fact that culture is not a neatly defined matter of us and them but rather a dynamic phenomenon that may take a particular form in any particular circumstance (see Cortazzi \& Jin, 1999; Kramsch, 1993; Kramsch, 1998; Savignon \& Sysoyev, 2005; Weninger \& Kiss, 2013). They will take into account the fact that an incident taking place in a British institution does not necessarily need to abide by categorical roles assigned to British culture-specifically, that the members and advisors of the debate team do not have to fit a Western notion of individualism but instead may show tendencies toward an ingroup mentality often attributed to Asian cultures (see Gudykunst, Lee, Nishida, \& Ogawa, 2005; Snow, 2014). Cultural meaning, then, is coconstructed by the members of a classroom culture which itself gives meaning to a cultural representation provided by an open text leading to an open task.

\section{CONCLUSION}

This paper has argued that the teaching of intercultural communicative competence in EFL settings requires the sharing of the responsibility of teaching ICC among the various courses of a curriculum. Since no one course can be held solely responsible for the teaching of ICC, the teaching of ICC must be consciously included in the design of all courses of the EFL curriculum. Any given course may have its own primary focus (e.g., integrated skills, global law), yet ICC should still stand as an underlying, consciously implemented component of the course. In other words, the instructor and/or materials designer cannot simply assume that students will naturally acquire ICC just because the instructor is from another culture (or has experience in another culture) or because the textbook contains factual information about other cultures.

JELTL (Journal of English Language Teaching and Linguistics), 4(1), 2019 


\section{John Harper}

If it is assumed that ICC needs to be included in all courses, a method of bringing about this inclusion is also needed. Hence, the present discussion has focused on one method (not the only one) that has been successful in the ELC of Shantou University-specifically, a textdriven, task-based method. Such a method, ultimately, is based on the notion of providing effective scaffolding. A text provides the scaffolding necessary to equip learners with the tools needed to carry out a task; the task allows learners to provide scaffolding for each other as they consider their inherited cultural positions, their personal positions, and the materials-represented positions of the other. Like cultures, tasks are open to change. The students carrying out a task, like the participants (whether local or "foreign") in a particular culture, will provide their own interpretations of things in keeping with their own knowledge and experience. Right and wrong answers are unlikely. With appropriate scaffolding, informed, thoughtful answers are probable.

Finally, the paper argues in favor of the inclusion of a variety of cultures in ICC instruction. As ICC instruction is about encountering differences, questioning beliefs and values, and providing interpretations, there would seem to be no reason to focus on a specific, hard-todefine target culture. As ICC instruction is also about making comparisons and contrasts, there would seem to be no reason to focus specifically on the source culture and thus to deny opportunities for cultural comparison/contrast. One may compare his/her own culture with any other culture as long as the other is made accessible with materials appropriate for the particular teaching context. By opening themselves up to a multitude of cultural similarities and differences, by learning to interpret and appreciate a multitude of differences, and by making a wide variety of comparisons and contrasts, learners may use their EFL classroom experience as a means of arriving at a truly global mindset.

\section{REFERENCES}

Allwright, D. (2005). From teaching points to learning points and beyond. TESOL Quarterly, 39(1), 9-31.

Allwright, R. L. (1984). Why don't learners learn what teachers teach? The interaction hypothesis. In D. M. Singleton \& D. G. Little (Eds.), Language in formal and informal contexts (pp. 3-18). Dublin, Ireland: IRAAL.

Baker, W. (2012). From cultural awareness to intercultural awareness: Culture in ELT. ELT Journal, 66(1), 62-70.

Bao, D. (2013). Developing materials for speaking skills. In B. Tomlinson (Ed.), Developing materials for language teaching (pp. 407-428). London, UK: Bloomsbury.

Block, D. (2003). The social turn in language acquisition. Edinburgh, UK: Edinburgh University Press Ltd.

Byram, K., \& Kramsch, C. (2008). Why is it so difficult to teach language as culture? The German Quarterly, 81(1), 20-34.

Byram, M. (1997). Teaching and assessing intercultural communicative competence. Clevedon, UK: Multilingual Matters. 
Byram, M., Gribkova, B., \& Starkey, H. (2002). Developing the intercultural dimension in language teaching: A practical introduction for teachers [Electronic Version]. Retrieved July 18, 2018 from http://www.lrc.cornell.edu/director/intercultural.pdf

Byram, M., \& Wagner, M. (2018). Making a difference: Language teaching for intercultural and international dialogue. Foreign Language Annals, 51(1), 140-151.

Cortazzi, M., \& Jin, L. (1999). Cultural mirrors: Materials and methods in the EFL classroom. In E. Hinkel (Ed.), Culture in second language teaching and learning (pp. 196-219). Cambridge, UK: Cambridge University Press.

Crabbe, D. (2003). The quality of language learning opportunities. TESOL Quarterly, 37(1), 934.

Crabbe, D. (2007). Learning opportunities: Adding value to tasks. ELT Journal, 61(2), 117-125.

Donato, R. (2004). Aspects of collaboration in pedagogical discourse. Annual Review of Applied Linguistics, 24, 284-302.

Dörnyei, Z. (2001). Motivational strategies in the language classroom. Cambridge, UK: Cambridge University Press.

Dörnyei, Z., \& Malderez, A. (1997). Group dynamics and foreign language teaching. System, 25(1), 65-81.

Dörnyei, Z., \& Murphey, T. (2003). Group dynamics in the language classroom. Cambridge, UK: Cambridge University Press.

Durocher, D. O. (2007). Teaching sensitivity to cultural difference in the first-year foreign language classroom. Foreign Language Annals, 40(1), 143-160.

Ellis, R. (2003). Task-based language learning and teaching. Oxford, UK: Oxford University Press.

Ellis, R. (2009). Task-based language teaching: Sorting out the misunderstandings. International Journal of Applied Linguistics, 19(3), 221-246.

Ellis, R. (2010). Second language acquisition research and language-teaching materials. In N. Harwood (Ed.), English language teaching materials: Theory and practice (pp. 36-64). Cambridge, UK: Cambridge University Press.

Ellis, R. (2011). Macro- and micro-evaluations of task-based teaching. In B. Tomlinson (Ed.), Materials development in language teaching (pp. 212-235). Cambridge, UK: Cambridge University Press.

Furstenberg, G. (2010). Making culture the core of the language class: Can it be done? The Modern Language Journal, 94(2), 329-332.

Gudykunst, W. B., Lee, C. M., Nishida, T., \& Ogawa, N. (2005). Theorizing about intercultural communication. In W. B. Gudykunst (Ed.), Theorizing about intercultural communication (pp. 3-32). Thousand Oaks, CA, USA: Sage.

Harper, J., \& Chen, H-J. (2018). Group dynamics and student participation in a Chinese setting: Teacher and observer perspectives. Journal of English Language Teaching and Linguistics, 3(1), 21-40.

Henry, A., Korp, H., Sundqvist, P., \& Thorsen, C. (2017). Motivational strategies and the reframing of English: Activity design and challenges for teachers in contexts of extensive extramural encounters. TESOL Quarterly. doi:10.1002/tesq.394. 


\section{John Harper}

Jolly, D., \& Bolitho, R. (2011). A framework for materials writing. In B. Tomlinson (Ed.), Materials development in language teaching (pp. 107-134). Cambridge, UK: Cambridge University Press.

Kearney, E. (2010). Cultural immersion in the foreign language classroom: Some narrative possibilities. The Modern Language Journal, 94(2), 332-336.

Kiet Ho, S. T. (2009). Addressing culture in EFL classrooms: The challenge of shifting from a traditional to an intercultural stance. Electronic Journal of Foreign Language Teaching, 6(1), 63-76.

Kim, Y., Jung, Y., \& Tracy-Ventura, N. (2017). Implementation of a localized task-based course in an EFL context: A study of students' evolving perceptions. TESOL Quarterly 51(3), 632660.

Kramsch, C. (1993). Context and culture in language teaching. Oxford, UK: Oxford University Press.

Kramsch, C. (1998). Language and culture. Oxford, UK: Oxford University Press.

Kumaravadivelu, B. (2002). Paying attention to inter- in intercultural communication. TESOL Journal, 11(1), 3-4.

Lantolf, J. P., \& Thorne, S. L. (2006). Sociocultural theory and the genesis of second language development. Oxford, UK: Oxford University Press.

Luke, A. (1989). Open and closed texts: The ideological/semantic analysis of textbook narratives. Journal of Pragmatics, 13, 53-80.

McKay, S. L. (2000). Teaching English as an international language: Implications for cultural materials in the classroom. TESOL Journal, 9(4), pp. 7-11.

Mercer, N., \& Howe, C. (2012). Explaining the dialogic processes of teaching and learning: The value and potential of sociocultural theory. Learning, Culture and Social Interaction, 1, 1221.

Menard-Warwick, J. (2009). Co-constructing representations of culture in ESL and EFL classrooms: Discursive faultlines in Chile and California. The Modern Language Journal, 93(1), 30-45.

Moeller, A. J., \& Faltin Osborn, S. R. (2014). A pragmatist perspective on building intercultural communicative competency: From theory to classroom practice. Foreign Language Annals, 47(4), 669-673.

Nation, I. S. P., \& Macalister, J. (2010). Language curriculum design. New York, US \& London, UK: Routledge.

Naughton, D. (2006). Cooperative strategy training and oral interaction: Enhancing small group communication in the language classroom. The Modern Language Journal, 90(2), 169-184.

Nunan, D. (1988). The learner-centred curriculum. Cambridge, UK: Cambridge University Press.

Nunan, D. (1995). Closing the gap between learning and instruction. TESOL Quarterly, 29(1), 133-158.

Nunan, D. (2004). Task-based language teaching. Cambridge, UK: Cambridge University Press.

Oxford, R. L. (1997). Cooperative learning, collaborative learning, and interaction: Three communicative strands in the language classroom. The Modern Language Journal, 81(4), 443-456. 
Perry, L. B., \& Southwell, L. (2011). Developing intercultural understanding and skills: Models and approaches. Intercultural Education, 22(6), 453-466.

Prabhu, N. S. (1987). Second language pedagogy. Oxford, UK: Oxford University Press.

Pulverness, A., \& Tomlinson, B. (2013). Materials for cultural awareness. In B. Tomlinson (Ed.), Developing materials for language teaching (pp. 443-459). London, UK: Bloomsbury.

Richards, J. C. (2001). Curriculum Development in Language Teaching. Cambridge, UK: Cambridge University Press.

Robinson, P. (2011). Task-based language learning: A review of issues. Language Learning, 61(1), 1-36.

Saraceni, C. (2013). Adapting courses: A personal view. In B. Tomlinson (Ed.), Developing materials for language teaching (pp. 49-62). London, UK: Bloomsbury.

Savignon, S. J. (2003). Teaching English as communication: A global perspective. World Englishes, 22(1), 55-66.

Savignon, S. J., \& Sysoyev, P. V. (2005). Cultural comparisons: Strategies for learners. Foreign Language Annals, 38(3), 357-365.

Scarino, A. (2010). Assessing intercultural capability in learning languages: A renewed understanding of language, culture, learning, and the nature of assessment. The Modern Language Journal, 94(2), 324-329.

Seedhouse, P. (2005). "Task” as research construct. Language Learning, 55(3), 533-570.

Sercu, L. (2002). Autonomous learning and the acquisition of intercultural communicative competence: Some implications for course development. Language, Culture and Curriculum, 15(1), 61-74.

Skehan, P. (1998). A cognitive approach to language learning. Oxford, UK: Oxford University Press.

Skehan, P. (2002). A non-marginal role for tasks. ELT Journal, 56(3), 289-295.

Skehan, P. (2003). Task-based instruction. Language Teaching, 36, 1-14.

Smith, L. (1976). English as an international auxiliary language. RELC Journal, 7(2), 38-42.

Snow, D. (2014). Encounters with Westerners: Improving skills in English and intercultural communication. Shanghai, China: Shanghai Foreign Language Education Press.

Snow, D. (2015). English teaching, intercultural competence, and critical incident exercises. Language and Intercultural Communication, 15(2), 285-299.

Snow, D. (2016). Affective factors and interpretive judgments in intercultural encounters. Intercultural Communication Studies, 25(3), 19-32.

Spencer-Oatey, H., \& Franklin, P. (2009). Intercultural interaction: A multidisciplinary approach to intercultural communication. London, UK: Palgrave Macmillan.

Tang, Y. (2006). Beyond behavior: Goals of cultural learning in the second language classroom. The Modern Language Journal, 90(1), 86-99.

Tomlinson, B. (2010). Principles of effective materials development. In N. Harwood (Ed.), English language teaching materials: Theory and practice (pp. 93-125). Cambridge, UK: Cambridge University Press.

Tomlinson, B. (2013a). Developing principled frameworks for materials development. In B. Tomlinson (Ed.), Developing materials for language teaching (pp. 95-118). London, UK: Bloomsbury. 


\section{John Harper}

Tomlinson, B. (2013b.) Materials evaluation. In B. Tomlinson (Ed.), Developing materials for language teaching (pp. 21-48). London, UK: Bloomsbury.

Van den Branden, K. (2009). Mediating between predetermined order and chaos: The role of the teacher in task-based language education. International Journal of Applied Linguistics, 19(3), 264-285.

Walker, G. (2000). Performed culture: Learning to participate in another culture. In R. D. Lambert \& E.

Shohamy (Eds.), Language policy and pedagogy (pp. 223-238). Philadelphia, US: John Benjamins.

Webb, N. B. (2009). The teacher's role in promoting collaborative dialogue in the classroom. British Journal of Educational Psychology, 79, 1-28.

Wells, G. (1999). Dialogic inquiry: Toward a sociocultural practice and theory of education. Cambridge, UK: Cambridge University Press.

Weninger, C., \& Kiss, T. (2013). Culture in English as a foreign language (EFL) textbooks: A semiotic approach. TESOL Quarterly, 47(4), 694-716.

Widdowson, H. G. (1994). The ownership of English. TESOL Quarterly, 28(2), 377-389.

Willis, J. (1996). A framework for task-based learning. London, UK: Longman. 